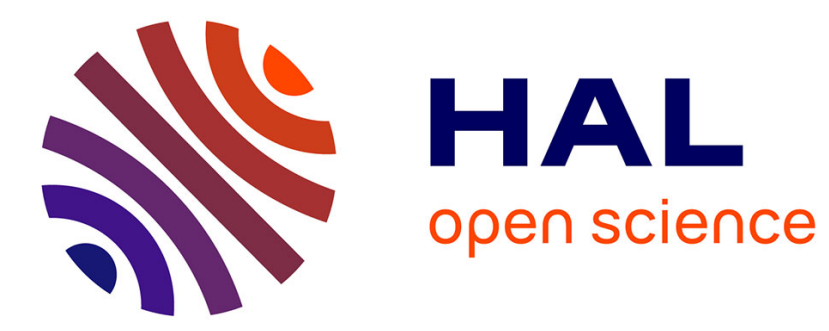

\title{
Subsidiary managers' knowledge mobilizations: Unpacking emergent knowledge flows
}

Esther Tippmann, Pamela Sharkey Scott, Vincent Mangematin

\section{To cite this version:}

Esther Tippmann, Pamela Sharkey Scott, Vincent Mangematin. Subsidiary managers' knowledge mobilizations: Unpacking emergent knowledge flows. Journal of World Business, 2014, 49 (3), pp.431444. 10.1016/j.jwb.2013.09.001 . hal-00864324

\section{HAL Id: hal-00864324 \\ http://hal.grenoble-em.com/hal-00864324}

Submitted on 20 Sep 2013

HAL is a multi-disciplinary open access archive for the deposit and dissemination of scientific research documents, whether they are published or not. The documents may come from teaching and research institutions in France or abroad, or from public or private research centers.
L'archive ouverte pluridisciplinaire HAL, est destinée au dépôt et à la diffusion de documents scientifiques de niveau recherche, publiés ou non, émanant des établissements d'enseignement et de recherche français ou étrangers, des laboratoires publics ou privés. 


\title{
Subsidiary managers'knowledge mobilizations: \\ Unpacking emergent knowledge flows
}

\author{
Esther Tippmann*, Dublin Institute of Technology \\ Aungier Street, Dublin 2, Ireland \\ esther.tippmann@gmail.com
}

Pamela Scott, Dublin Institute of Technology

Aungier Street, Dublin 2, Ireland

pamela.sharkeyscott@dit.ie

Vincent Mangematin, Grenoble Ecole de Management

12 Rue Pierre Semard, 38000 Grenoble, France

Vincent.mangematin@grenoble-em.com

* Corresponding author. 


\title{
Subsidiary managers'knowledge mobilizations: Unpacking emergent knowledge flows
}

\begin{abstract}
Knowledge flows are a key source of advantage for multinational corporations (MNCs). As research on subsidiary knowledge flows to date has mostly focused on organization-level investigations, often using quantitative methodologies, the nuances of knowledge flows practices and their micro-foundations require further theoretical development. Using detailed qualitative data on 40 cases of subsidiary managers' knowledge mobilizations, this paper unravels some of the micro-level practices of knowledge mobilizationsin MNCs. We find that subsidiary manager's knowledge mobilization practices initiate a complex pattern of subsidiary knowledge inflows, pinpointing the significance of lateral and bottom up exchanges (locally as well as internationally)and the emergent nature of utilizing practices, specialist skills and expertise, as well as experience and advice to develop solutions. We use these insights to distinguish between two types of subsidiary knowledge flows: deliberate and emergent knowledge flows and highlight how their differences have profound implications for the investigation of subsidiary and MNC knowledge flows and their microfoundations.
\end{abstract}

Keywords:knowledge flows, knowledge transfers, MNC/MNE, knowledge seeking behavior, middle managers, subsidiary 


\section{Introduction}

Knowledge flows are an important source of advantage for multinational corporations (MNCs) (Gupta \& Govindarajan, 2000; Kogut \& Zander, 1993; Mudambi, 2002), and there are two main ways that make knowledge flows in the MNC strategically important. First, knowledge might be shared for reuse and leverage, i.e. flow from an 'advanced' knowledge creating unit to other units which then implement and utilize the generated knowledge. This leads to a reuse of technologies, practices, processes and competence across the MNC (Ghoshal \& Bartlett, 1988; Kostova, 1999; Kostova \& Roth, 2002; Szulanski, 1996; Szulanski \& Jensen, 2006; Zander \& Kogut, 1995). Second, knowledge flows in the MNC serve as inputs for knowledge creation whereby different existing knowledge is integrated and blended to create new knowledge (Almeida \& Phene, 2004; Ghoshal \& Bartlett, 1988; Kotabe, Dunlap-Hinkler, Parente, \& Mishra, 2007; Phene \& Almeida, 2008; Regner \& Zander, 2011; Tsai, 2001). Indeed, MNCs exhibit a unique combinative capability to enhance existing and build new competences (Kogut \& Zander, 1992). Although knowledge flows can serve different purposes, including operational and day-to-day exchanges, this paper is concerned with such competence impacting knowledge flows from a subsidiary perspective.

Research on MNC knowledge flows taking a subsidiary perspective has seen considerable interest over the last couple of years, and Michailova and Mustaffa (2012) highlight two important gaps in this literature that this paper directly addresses. One, previous studies on knowledge flows are heavily biased towards quantitative examinations, leaving under-explored specific practices that relate to knowledge flows, although unearthing the nuances of such practices can 
yield a more grounded and conceptually refined understanding of knowledge flows (see also Tallman \& Chacar, 2011a; Tallman \& Chacar, 2011b). By qualitatively investigating the details of subsidiary mangers' knowledge mobilizations across 40 responses to non-routine problems sampled from four subsidiaries, this paper develops insights on competence impacting subsidiary knowledge flows. Based on the results we develop the notion of deliberate and emergent knowledge flow to capture the characteristics of two types of competence impacting knowledge inflows that subsidiary managers engage in.

Two, Michailova and Mustaffa (2012) conclude that subsidiary characteristics have been the predominant focus of pervious research at the expense of analyzing knowledge flows at the level of the individual. There have been repeated calls to examine knowledge flows at the micro-level to unravel micro-foundations which deepen and develop more fine-grained insights on the role and influence of individual behavior and individual agency on knowledge flows (Doz, 2006; Foss, 2006; Foss \& Pedersen, 2004; Mäkelä, Andersson, \& Seppälä, 2012; Minbaeva, Mäkelä, \& Rabbiosi, 2012). Investigating what kind of subsidiary knowledge inflows are initiated by subsidiary managers in response to specific non-routine problems that they encountered, this paper adds to our understanding of knowledge flow practices in MNCs, which directly bears on questions micro-foundations of knowledge flows.

The next sections introduce the theoretical background to our examination of competence impacting knowledge flows initiated by subsidiary managers. We then outline our methodology for this exploratory study and present the main findings. The implications for scholarly understanding of subsidiary knowledge inflows and knowledge flow micro-foundations are 
discussed, followed by a detailed consideration of future research and managerial implications.

\section{Theoretical background}

2.1. Knowledge inflows as outcome of knowledge mobilizations driven by problemistic search

As Michaliova and Mustaffa(2012) offer a comprehensive and systematic review of over 60 articles to outline the main findings regarding subsidiary knowledge flows, we only outline and justify here the theoretical framing that was employed to investigate competence impacting knowledge inflows initiated by subsidiary managers.

A way to examine how subsidiary managers mobilize knowledge is to examine their problemistic search, defined as motivated search in response to non-routine problems (Cyert \& March, 1963). Non-routine problems are unusual organizational challenges for which the current processes and practices lack a pre-determined or routinized response (Nelson \& Winter, 1982). These nonroutine problems are triggered by current or anticipated changes in the environment and cause a behavioral response in the form of solution searching which is aimed at closing this mismatch between current organizational processes, practices and competences and the changing requirements in the marketplace. This motivated search behavior may lead to relevant knowledge to be sought and selected (Schulz, 2003), and has been previously linked to MNC knowledge flows (Monteiro, Arvidsson, \& Birkinshaw, 2008; Zellmer-Bruhn, 2003), as it leads to subsidiary knowledge inflows if knowledge is mobilized from other MNC units to assist the subsidiary-level solution finding activities. 
In contrast to responses to day-to-day or routine problems, problemistic search is a rarer event and one of the main ways how organizations achieve continuous, evolutionary adaptation if solutions are implemented that change espoused processes and practices at the subsidiary or MNC level(Tippmann, Scott, \& Mangematin, 2010). Given their significance for organizational adaptation, this also means that non-routine situations are often complex and ambiguous, and may pose high knowledge needs(Nickerson \& Zenger, 2004), so making it a suitable approach for investigating actual knowledge mobilizations in the MNC and how these knowledge mobilizations relate to conceptualizations of subsidiary and MNC knowledge flows.

2.2. MNC knowledge flows at the individual-level: The central role of subsidiary managers

Departing from the common emphasis on using the subsidiary as level of observation of knowledge flows and responding to the need for micro-level investigations (Foss, Husted, \& Michailova, 2010; Foss \& Pedersen, 2004; Minbaeva, Foss, \& Snell, 2009), we pursued an individual-level approach that seeks to unravel explanatory mechanisms of organizational knowledge flows at the level of individuals by focusing at their actions and interactions (Felin \& Foss, 2005; Felin \& Hesterly, 2007). Fundamentally, knowledge flows depend on human interactions and people's abilities to transfer knowledge (Argote \& Ingram, 2000; Argote, Ingram, Levine, \& Moreland, 2000; Argote, McEvily, \& Reagans, 2003; Noorderhaven \& Harzing, 2009): it is not units as such that exchange knowledge, but individuals within those units. Previous studies that examined MNC knowledge flows from the perspective of the individual focused 
for example on expatriates (Bonache \& Zárraga-Oberty, 2008; Crowne, 2009; Engelhard \& Nägele, 2003; Hocking, Brown, \& Harzing, 2004, 2007; Lazarova \& Tarique, 2005), knowledge workers(Sunaoshi, Kotabe, \& Murray, 2005) or general knowledge sourcing efforts within MNCs (Teigland \& Wasko, 2009). Aligning with our emphasis on competence impacting knowledge flows, we build on the middle management perspective of the strategy and organizational knowledge literatures to argue that subsidiary managers - as the middle managers of the MNC - are the nexus for MNC knowledge flows that relate to organizational competences.

With the rise of networked or heterarchical structures of MNCs, subsidiaries in general have a more central role in the exchange of knowledge, receiving knowledge from headquarters and other units, and, in addition, many subsidiaries have developed their potential to create and then share their knowledge with other MNC units (Bartlett \& Ghoshal, 1998; Ghoshal \& Bartlett, 1990; Gupta \& Govindarajan, 1991, 2000). Within such a complex and decentralized architecture of MNCs, characterized by vertical and lateral knowledge flows across different hierarchical levels of the organization, middle managers undertake the critical task of mediating, catalyzing and leading knowledge exchanges (Hedlund, 1994; Nonaka, 1994).

While front-line staff might possess and require knowledge that is very specific to their immediate task environment, and top management provides strategic direction and knowledge with regards to the general product-market, technological or geographical domain (Mom, Van Den Bosch, \& Volberda, 2007), middle managers operate at the nexus where this specific, bottom up knowledge and general, top-down knowledge collide. Interacting across these 
vertical interfaces offers subsidiary managers channels to mobilize knowledge from subsidiary front-line and higher-level management both, located at the focal subsidiary and other international sites.

Middle managers are also critical in developing and maintaining the lateral connections within large organizations such as MNCs(Hedlund, 1994; Nonaka, 1994), interacting with management peers across functional and geographic boundaries. Such lateral communication across geographic boundaries is an important integrating device within the MNC to manage the dispersion of the organization (Ghoshal, Korine, \& Szulanski, 1994), and subsidiary managers may utilize these horizontal links to mobilize knowledge (Mors, 2010).

Many emerging organizational challenges such as non-routine problems are experienced first by front-line staff and then brought to middle management's attention(Burgelman, 1983; Floyd \& Lane, 2000). Subsidiary managers are thus often closer to the emerging organizational challenges of the subsidiary and MNC compared to global top management. In leading suitable responses to these challenges, it has been found that middle managers may crossleverage capabilities by 'moving' existing capabilities to areas where they believe these capabilities can generate value (Taylor \& Helfat, 2009). It has also been established that top-down knowledge inflows to middle managers tend to foster exploitation, and horizontal and bottom up knowledge inflows more likely lead to exploration (Mom et al., 2007).

Given that most research on subsidiary knowledge flows has taken an aggregated perspective, for example, by asking subsidiary top managers to indicate how much knowledge the subsidiary received over a given time period 
(e.g. Ambos \& Ambos, 2009; Björkman, Barner-Rasmussen, \& Li, 2004; Driffield, Love, \& Menghinello, 2010; Gupta \& Govindarajan, 2000; Monteiro et al., 2008; Schulz, 2001, 2003; Tsai, 2001, 2002), or analyzed patent citations (Kotabe et al., 2007), investigating problemistic search in response to particular challenges allows developing a more nuanced view of how knowledge inflows that may appear in these summary measures are actually initiated in practice. Further, developing our understanding of subsidiary managers' knowledge mobilization practices will inform research on the micro-foundations of knowledge flows by revealing some of the details of how subsidiary managers engage in knowledge inflows in practice.

Although the strategy and organizational knowledge literatures highlight the critical role of middle managers in catalyzing knowledge exchanges, to our knowledge, this perspective has not yet been systematically applied to the MNC context. Thus, questions remain with regards to how subsidiary management (as the MNC's middle managers) utilize the different channels for knowledge mobilization in practice and how that influences competence impacting knowledge flows in the MNC.

\section{Method}

\subsection{Research design and setting}

While there has been much research on knowledge flows in MNCs, how subsidiary managers actually mobilize knowledge in practice is not well understood. Given thisexploratory nature and theaim of generating a better understanding, a case study design was particularly suited to this research,allowing us to gain an in-depth understanding of subsidiary managers' 
knowledge mobilizations by enquiring closely into their actions and thus appreciating the real-life complexities of MNCknowledge processes (Eisenhardt, 1989; Yin, 2009).

Following theoretical sampling (Pauwels \& Matthyssens, 2004), our study was conducted in four, wholly-owned, greenfield subsidiaries of four different MNCs in the ICT industry. This replication logic (Eisenhardt, 1989; Yin, 2009) is an empirical advantage in the exploration of MNC knowledge mobilizations as there is need for research to "move away from examining knowledge flows in subsidiaries of single MNCs. Instead, the focus should be on subsidiaries of several MNCs" (Michailova \& Mustaffa, 2012, p. 391) to generate findings of greater theoretical transferability. The foursubsidiaries - all located in Ireland and part of two US and two European MNCs -are here called Epsilon, Gamma, Omega and Sigma to preserve their anonymity. While all MNCs were chosen from a single industry to reduce extraneous variation the four subsidiaries were selected to represent a range of different variables at the corporation (MNC) and subsidiary levels (see Table 1) - including aspects that have previously been found to influence knowledge flows. This introduced theoretical variation into our investigation of subsidiary managers' practices in mobilizing knowledge. The focal subsidiaries were of different sizes, indicating different levels of knowledge stocks (Gupta \& Govindarajan, 2000; van Wijk, Jansen, \& Lyles, 2008), and had different numbers and types of mandates, a sign of the concentration and scope of their knowledge (Gupta \& Govindarajan, 2000; Hansen \& Løvås, 2004; van Wijk et al., 2008). In addition, the structure of the MNCs' international operations varied sufficiently to incorporate local, regional and global subsidiary responsibilities. These factors translated into different 
levels of subsidiary autonomy and of international integration and interdependencies (O'Donnell, 2000), which influence knowledge flow patterns (Gupta \& Govindarajan, 2000; Hansen \& Løvås, 2004). Due to the focus on nonroutine problems encountered by individual subsidiary managers, subsidiaries had to be large enough to ensure adequate numbers of possible middle management respondents.

Theoretical sampling was also used to select subsidiary middle manager interviewees. They were sampled widely to include managers from $R \& D$, operations, sales, services and support units, and their company tenures varied (from one to 18 years) suggesting different time spans for building interpersonal networks and social capital which can serve as valuable channels for knowledge sharing in particular in large and geographically distributed organizations like MNCs (Hansen, 1999; Inkpen \& Tsang, 2005; Mäkelä \& Brewster, 2009; Mors, 2010). Although some subsidiary managers were home country or third country nationals, most were host country nationals, and some had previously been expatriates. Having undertaken an international assignment in the past may help the subsidiary manager to 'know-who' in developing a more-wide ranging interpersonal network(Dickmann \& Harris, 2005; Hocking et al., 2004).

\section{Insert Table 1 here}

\subsection{Data collection}

We used multiple data collection techniques - study of secondary sources, 34 interviews with subsidiary middle managers (referred to as 'subsidiary managers' throughout the paper), 7 interviews with subsidiary senior managers, and a review of archive materials - to gather informationabout the 
subsidiariesand their parent MNCs more generally, as well as in-depth data about subsidiary managers' knowledge searches. The semi-structured interviews with subsidiary managers were the main data collection technique and used to identify the specific non-routine problems involved and the corresponding knowledge mobilization (i.e. knowledge searched for, identified and mobilized to initiate and enact a subsidiary knowledge inflow), the main unit of analysis for this article. These interviews lasted approximately one hour (some up to 75 minutes), with the main focus on gathering material on specific aspects directly relating to knowledge searches. Respondents were asked to recall one or two specific nonroutine problems and explain how they searched for knowledge as part of their solution finding process for each incident. We sought information on situations that occurred during the past year, to allow for an accurate recall of events (Huber \& Power, 1985), and used open-ended questions and probes to encourage detailed responses as well as to promote more accurate recall of specific actions and interactions rather than more general opinions or beliefs (Miller, Cardinal, \& Glick, 1997). These prompts were particularly useful to elicit where exactly the knowledge was searched and what kind of knowledge was mobilized. Interviews were recorded, transcribed verbatim and verified with respondents to ensure their accuracy.

Seven senior-level subsidiary managers, including Business Directors and General Managers, were interviewed to gain a deeper understanding of the MNC's knowledge processes and how the subsidiary normally exchanged knowledge with other parts of the organization. Five of these interviews were recorded and transcribed verbatim; detailed notes were taken and transcribed immediately afterwards in the other two. These senior management interviews 
also provided additional detail on the solution finding which we combined with archival information and data from subsidiary management interviews for triangulation.

We collected data on 42 cases of non-routine problems, but dropped two from the analysis due to missing detail, resulting in a final dataset of 40 cases. Importantly, a detailed post-hoc analysis of the solutions implemented revealed that they mostly led to changes in routines (modifying existing or creating new routines) or created new technology components, so contributing to the renewal of competences at the subsidiary and even MNC level. In addition, the urgency and potential of causing a negative impact on operational performance required that the subsidiary managers developed a solution to resolve the initial challenge.Table 2 brieflysummarizes the range of non-routine problems included in the dataset.

\section{Insert Table 2 here}

\subsection{Data analysis}

The data analysis progressed through multiple phases, starting with identifying knowledge components. As typical for complex systems, organizational knowledge is decomposable into different components, i.e. its constituent parts that in their interdependence build a knowledge architecture or organizational knowledge system(Henderson \& Clark, 1990; Simon, 1962). Following this notion, we initially identified all the variousknowledge components - internal and external - which the subsidiary managers mobilized as part of their solution finding. Knowledge flows comprise search and transfer 
(Hansen, 1999), so careful attention was paid to coding only those components that were actually exchanged and excluding those which, although identified aspart of thesearch,were not mobilized. As the right column of Table 2 shows, a total of 146 knowledge components were identified, with a considerable variation (from zero to ten) across the cases.

We then examined these 146 knowledge components to identify the constituent sub-themes. To give our analysis an early structure, and to facilitate cross-case comparison, these knowledge components where classified under the broad, literature-based dimensions (Miles \& Huberman, 1994) of tacit and explicit knowledge. Tacit knowledge refers to knowledge which is difficult to articulate and accumulates through experience; whereas explicit knowledge can be expressed easily and codified (Polanyi, 1966). We then coded these knowledge components into the major themes identified from the data: (1) declarative knowledge, (2) practice - process embedded in document, tools, technology, (3) experience, advice, (4) practice - understanding of practice, and (5) specialist expertise, competence.

To analyze knowledge mobilization patterns, i.e. the sources of inflowing knowledge(Foss \& Pedersen, 2002), we examined whether internal knowledge components were sourced vertically (either bottom upfrom front-line staff/management or downwards from top management) or horizontally from middle management peers, or from a central knowledge database (repository). We explored the geographic proximity of targeted knowledge sources, crosscoding all knowledge components as being sourced locally (from the same subsidiary) or internationally (from another international location of the MNC). For each knowledge exchange (which totaled 122, as managers may have used 
one knowledge source for more than one knowledge component), we also coded whether the knowledge was sourced internally - from within the same or another function - or externally, to account for further subtleties in the diversity of knowledge sources targeted. After completing the within-case analysis, we generated a meta-matrix by 'stacking' the 40 cases under common codes (Eisenhardt, 1989; Miles \& Huberman, 1994) reflecting the knowledge components mobilized and the sourcing patterns involved (local/international, lateral/vertical, within/across functions, internal/external). This meta-matrix represented a highly condensed presentation of the within-case analysis and greatly facilitated comparison across the 40 cases.

Overall, multiple measures were employed to strengthen the trustworthiness of the qualitative data and analysis (Lincoln \& Guba, 1985): multiple data analysis iterations; constant moving between data and theory; protecting confidentiality; confirming the validity of preliminary analyses with respondents; and using NVivo to perform a systematic and consistent analysis of knowledge mobilization practices.

\section{Findings}

The first two data analysis phases revealed the main themes of those knowledge components that the subsidiary managers mobilized across the 40 cases: Table 3 provides supporting data for each theme, while Figure 1summarizesour findings about knowledge inflow patterns and depicts the intensity and sources of those different knowledge components. For illustrative purposes, we present our findings in a descriptive format along the knowledge component themes, although,in most cases, knowledge search processesunfolded 
in practicein more idiosyncratic, complex and iterative ways.

\section{Insert Table 3 here}

\section{Insert Figure 1 here}

\subsection{Experience and advice}

The subsidiary managers we interviewed valued the experience and advice of others. Although mobilizing experience by itself can reinforce previousknowledge accumulation paths and thus cause inertia, it can also stimulate creative outcomes if reframed through the interpersonal interactionof seeking help (Hargadon \& Bechky, 2006). Valuing the knowledge located at the same site and the efficacy of face-to-face exchanges, subsidiary managers sought experience from peers in local management who might have encountered similar issues in their particular areas. They asked for advice within their local management teams, occasionally including subsidiary senior management and also front-line employees, whose bottom up knowledge brought deeper understandings of problem subtleties and trustworthy, first-hand advice for solution crafting: "while she is not a manager, she has huge experience...I trust her. She has a very good brain. ...she is somebody whose opinion is well worth hearing" (Epsilon, case 2); "the experience from our team. ... This is the informal, very practical experience” (Gamma, case 12).

This search for experience and advice also included colleague managers from other sites, again on the basis that they might may have previously encountered similar challenges: "we [Irish and US sister units] share knowledge and experience. When that comes into play mostly is when we have a critical 
situation" (Sigma, case 10). In such situations, the subsidiary managers usually either belonged to the same MNC group or division, or could draw on existing inter-personal relationships. Seeking experience and advice was mainly geared towards understanding and (re-)framing the non-routine problem involved, as well as seekingfurther input for achieving solutions: commonly reportedactions included approaching "experienced" colleagues "as peers" to obtain "their advice" and to "share" experience openly.

\subsection{Practice - process embedded in document, tools, technology}

Many organizations codify their practices and processes so as to enhance learning (Zollo \& Winter, 2002)and promote knowledge standardization to speed upreplication: practice elements can be carried and embedded in software tools and technologies as well as in documents (Zander \& Kogut, 1995). Our data suggests subsidiary managers were often interested in building on and reusing suitable elements of existing "best" or "good work" practices: "This was an established, recognized way" (Epsilon, case 2) so as to "take the best of what they were doing" (Gamma, case 13). Interestingly, these practices were sourced more intensely from international sources, both laterally and bottom up, than locally, with subsidiary managers mobilizing selected practice elements embedded in documents, tools and technology; commonly expressed as taking the " model", "tools"or "program": "There is actually a lot of material there that can be taken. It doesn't need to be created from scratch" (Gamma, case 4); "There are a lot of tools, best practice and processes that have been set up. So, we cannot use all of them, but we can learn hell of a lot of what happened there" (Gamma, case 7). Being embedded in artifacts facilitated searching and 
moving these knowledge components, but the propertiesof the mobilized knowledge often remainedrather general,so additional understanding of tacit elements was usually required for its successful performance.

\subsection{Understanding of practice}

Despite the efforts of many organizations to codify practices, much important knowledge related to routine performance - including the exact workings of different micro-level practice elements - remained causally ambiguous and tacit (and thus harder to share)and contextual, so that its mobilization required more effort. The data shows that subsidiary managers often searched and mobilized this tacit practice understanding - the 'how' element -by seeking detailed explanations of how to perform the process/model in everyday practice to give them a deeper understanding of the complexities involved: "they serve as kind of council ... they can really talk you through of how exactly they handled it" (Gamma, case 11); "they [management peers in the US] understood the challenges we were going through and could help us to understand how they had managed issues like that" (Omega, case 1).

As with sourcing embedded practices, this type of knowledge exchange occurred more often between subsidiary managers internationally than locally. Global management peers were approached to gain understanding of routines in broader practice contexts, or to "understand the success" of routines (Gamma, case 13) by learning more about the approaches other units took towards similar issues. Subsidiary managers visited sister sites to gain more in-depth understanding, and also sourced tacit practice understandings from front-line employees who possessed therelevant "ground level or base level" (Sigma, case 
3) knowledge. The managers also organized moving employees, usually on short term assignments, to transfer tacit knowledge and assist the focal unit team to learn and implement particular practices.

\subsection{Specialist expertiseand competencies}

The novelty and complexity of many non-routine problems meant that developing solutions often required specialized knowledge - the specific "technical skill"held by a subject matter "expert" or "specialist". Our data reveals three particularly noteworthy findings. First, the search for specialist expertise and competencies exhibited the highest intensity of all knowledge components mobilized. A subsidiary manager described how an expert was his "main source of technical information ... and I would rely on that specific knowledge" (Epsilon, case 2). Second, a high proportion of such exchanges involved spanning functional boundaries assubsidiary managers searched for ahighly specialized unit or for individual peers with a particular competence/skill profile. Sales managers reached out to engineers, services managers to operations experts and operations managers to high-tech, $\mathrm{PhD}$ researchers: "That's a highly skilled team of PhDs, statisticians, mathematicians" (Gamma, case 13); "from their skill set; very smart and bright people" (Gamma, case 9). While these exchanges within and across functions occurred among subsidiary management peers locally, they were mostly between the subsidiary manager and front-line experts (local as well as global) depending on the location of the particular subject matter expert(s).Third, the majority of external knowledge mobilizations fell into this last category, suggesting subsidiary managers sought very specific tacit knowledge when approaching external sources to deal with non-routine 
problems.

\subsection{Declarative knowledge}

While subsidiary managers (of course) gathered and analyzed information and data, declarative knowledge - such as "technical documents"were only sought on rare occasions, either internally and externally, as "it is very difficult to understand the exact reasons" (Gamma, case 12) behind problems and develop solutionsusing only previously prepared descriptive knowledge. Sourcing declarative knowledge involved searching the MNC's knowledge repository, browsing the web and enquiring from management peers, but (as previous studies have observed) subsidiary managers clearly preferred more interpersonal search modes, for tacit and for explicit knowledge alike, even though well-developed knowledge repositories and modern IT technologies have transformed knowledge storage and access possibilities (Cross \& Sproull, 2004; De Aiwis, Majid, \& Sattar Chaudhry, 2006).

\subsection{External knowledge}

We found that subsidiary managers chose internal knowledge much more often than external knowledge.Where external knowledge was mobilized,subsidiary managers worked equally often with local, host-country sources and with geographically distant collaborators. It seems that, when external tacit knowledge was needed, subject matter expertise was a more critical factor than geographic proximity.

Our results show that subsidiary managers mobilized different kinds of knowledge components to deal with non-routine problems at their subsidiary 
units (see Table 4 for a summary of frequencies). Although each knowledge search process was idiosyncratic - including a number of cases with low and high intensity knowledge searches, common patterns emerged across the cases which included the mobilization of elements of existing practices, embedded in documents, tools and technology as well as the understandings required for their performance. Where practices were mobilized, they were usually recombined and blended with additional knowledge, complemented with specialist expertise or competence, as well as with experience and advice, to create modified or completely new solutions. Subsidiary managers mostly mobilized knowledge laterally from their management colleagues, as well as vertically from front-line employees. Their searches included local as well as international sources, and involved a nearly balanced mix of within-function and cross-functional flows but internal knowledge searches outweighed external ones.

\section{Insert Table 4 here}

\section{Discussion}

Competence impacting subsidiary knowledge flows contribute towards the realization of the MNC's combinative capability through searching and transferring knowledge that can be recombined to create new knowledge and competences; in other instances, competence impacting knowledge flows are the manifestation of $\mathrm{MNC}$ strategies to internationally replicate competences, processes and practices to reuse and leverage 'superior' knowledge in different locations. A recent review of the literature on subsidiary knowledge flows points out two key areas that are in need for further theoretical development 
(Michailova \& Mustaffa, 2012): (1) qualitative research to explore in detail specific practices relating to knowledge flows, and (2) attention to individuallevel knowledge flows to develop insights on the micro-foundations of MNC knowledge flows. By investigating subsidiary managers' actual knowledge mobilization practices and their knowledge mobilization pattern as they seek to develop responses to non-routine problems, this research directly addresses these two opportunities for theory development.

5.1. Subsidiary managers' practices of knowledge mobilization: Unpacking the emergent knowledge flow

\section{Insert Table 5 here}

This article's main contribution relates to increasing our understanding of MNC knowledge flows. One kind of MNC knowledge flows is the leverage of 'superior' competences, usually generated by headquarters or advanced subsidiaries with creative roles (Meyer, Mudambi, \& Narula, 2011). As a MNC's knowledge related advantages hinge on its ability to transfer competences internally effectively and efficiently, such competence impacting knowledge flows are a central part of MNC strategy, andsubstantial efforts have been made to build and improve MNCs' capacities to leverage 'superior' processes and practices across their dispersed operations.

This strategic importance of competence impacting knowledge flows has caused MNCs to develop different strategies to managing this critical replication effort (Baden-Fuller \& Winter, 2007; Szulanski \& Jensen, 2006). Szulanski(2000) describes the routinization of competence replication, referring 
to the directing role of the parent organization, and it is also noted that subsidiaries may be "confronted with internal organizational pressure from their parent company to adopt a practice"(Kostova, 1999; Kostova \& Roth, 2002, p. 217). Even in lateral transfers between subsidiary units, headquarters might have a direct involvement in directing and participating in these exchanges (Ciabuschi, Dellestrand, \& Kappen, 2011; Yamin, Tsai, \& Holm, 2011), and such headquarters involvement is more likely if corporate value creation could be at stake (Poppo, 2003). Overall, MNC management often decides strategically on what knowledge is leveraged and when, and on the processes/strategies for executing such replication efforts. Drawing on Mintzberg and Waters (1985), we summarize this type of knowledge exchange under the term deliberate knowledge flows (as summarized in the left column of Table 5) which denotes an intentional, top management-driven strategic effort to managing the pattern of competence impacting knowledge exchanges. The role of subsidiary management is to ensure inflowing knowledge is adopted and implemented, and to avoid the risk of minimal (or even ceremonial) adoption (Kostova \& Roth, 2002). The task of front line employees is to internalize the knowledge, and they may undertake certain adaptations to respond to local, context specific needs but overall, such knowledge flows unfold top-down within subsidiaries.

In contrast, the less well-researched knowledge mobilization practices of subsidiary managers (summarized on the right of Table 5) allows to consider MNC knowledge flows from a middle management perspective. Applying a middle management perspective to MNC knowledge flows not only unearths some of the actual practices of knowledge mobilization to access and apply the most appropriate knowledge in a particular situation, it also permits to develop 
insights on a particular kind of knowledge flow practice. The investigation of practices relating to knowledge flows is one of the main areas of the subsidiary knowledge flow literature which requires further theory development (Michailova \& Mustaffa, 2012).

We found that subsidiary managers often source existing practices or routines located both within and outside their focal functions, and both geographically nearby and distant. They frequently complement these knowledge inflows with specialist expertise and competences, and specific experience and advice, drawing on the practice understandings of front-line employees as well as from management peers. Together, these mobilizations display a complex pattern of competence impacting knowledge flows within MNCs (see Figure 1), revealing substantial lateral as well as bottom up transfers. Importantly, our data implies that these knowledge flows are not directly guided by top management's deliberate intentions and show the important additional role of front line employees in providing their specialist understanding, skill and adviceto actively assist solution development. In line with their lateral and bottom up characteristics, we label such transfers emergent knowledge flows (see Mintzberg and Waters 1985). Although the following discussion builds on these findings to develop this notion, the distinction between emergent and deliberate knowledge flow in practice is less of a sharp contrast and more of a gradual continuum.

Emergent knowledge flows exhibit properties that both complement and challenge certain assumptions about competence impacting knowledge flows in MNCs. First, we observe a lot of lateral knowledge mobilizations between management peers, occurring within and across functional boundaries, locally as well as internationally. We see this as evidence of inter-unit communication, 
social capital and the internal embeddedness of subsidiary managers - important enablers of knowledge flows (Gnyawali, Singal, \& Mu, 2009; Tsai, 2000; Tsai \& Ghoshal, 1998). In addition, the importance of lateral knowledge flows combined with very low knowledge mobilization from the top resonates with findings that laterality and cooperation between subsidiaries - without headquarters involvement - promote more efficient and effective knowledge transfers (Ciabuschi et al., 2011; Yamin et al., 2011). Our findings, however, add another consideration to questions of headquarters involvement in knowledge flows: we find not only that MNC headquarters were often uninvolved in these lateral flows, but that they even occurred 'below their radar' and thus beyond their direct control. So - at least in the problemistic search situations studied here - top management may have had little influence in practice on what knowledge components got mobilized and recombined by subsidiary management in perhaps ways that were unpredicted and unplanned by top management. The solutions created by the subsidiary managers we interviewed often modified existing or developed new routines and technologies, thus initiated changes to the building blocks of organizational MNC competences and capabilities (Dosi, Faillo, \& Marengo, 2008; Winter, 2003). This pinpoints towards the decentralization of competence development in the MNC(Birkinshaw, Hood, \& Jonsson, 1998; Rugman \& Verbeke, 2001; Tippmann et al., 2010). It also suggests an additional consideration about how MNC top management can best be involved in knowledge flows: we argue that it can only influence emergent knowledge flows indirectly, but that developing strategic vision at the subsidiary manager level can be critical to promoting knowledge mobilizations which while perhaps unplanned by top management and emergent - can lead to valuable 
solutions that contribute to developing bottom up a MNC's competences.

Second, deliberate knowledge flows occur mostly within functional domains, as replication strategies aim to copy closely superior, 'proven' knowledge in sister units. Although we also observed considerable withinfunction knowledge flows, the novelty of non-routine problems often required subsidiary managers to search across functional boundaries to look for unique, better-suited knowledge in other functional areas. The subsidiary managers then acted as boundary spanners (Kostova \& Roth, 2003), thereby overcoming the bias of inter-personal knowledge sharing in often remaining concentrated on the focal function (Mäkelä, Andersson, \& Seppälä, 2011). Such boundary spanning activities have become increasingly important, but also challenging, given modern MNCs' increasing architectural complexity and knowledge dispersion (Mudambi \& Swift, 2011). Emergent knowledge flows represent one example of how subsidiary managers can bridge interfaces to help MNCs achieve crossfunctional knowledge leverage. By actively initiating boundary spanning flows, these actions introduce diverse knowledge into focal units, increasing their potential to develop innovative and creative solutions. This is a key contrast to the potential of deliberate knowledge flows which tend to lead to relative convergence and uniformity as the overarching goal is to 'copy' knowledge internationally.

Third (and related to the above), problemistic search and resulting emergent knowledge inflows are linked to renewing MNC competences. Importantly, we found that subsidiary managers often mobilized knowledge components not for straight reuse or implementation, but for recombination, integrating different components to generate new knowledge - showing 
subsidiaries' potential for competence development. Their efforts in this regard should not be underestimated: Galunic and Rodan(1998) argue that the dispersal of knowledge in MNCs decreases the likelihood of novel uses of existing knowledge being detected, making it more difficult for subsidiary managers to conceive and conceptualize novel knowledge recombinations. Considering the current trend for MNC operations to be increasingly fine-sliced into narrower mandates in the pursuit of a global factory model (Buckley, 2009), which in turn further increases the structural complexity of MNCs and the specialization of knowledge (Mudambi \& Swift, 2011), we can expect this challenge to become further exacerbated. The simultaneous decentralization of MNC strategic knowledge processes and the increasing rate of environmental change in many industries - made more complicated by local, regional and global trends - will require fast and creative solution development at the subsidiary level, making it even more important to develop subsidiary managers' capacities to initiate emergent knowledge flows.

We also found that subsidiary managers' abilities to source knowledge from the front-line required the tensions rooted in different 'professional guilds' to be overcome(Mudambi \& Swift, 2009). Where different knowledge components are utilized, the emergent knowledge flow then becomes part of the subsidiary's (re-)combinative activities, developing organizational knowledge in line with changing environmental conditions (Kogut \& Zander, 1992) and introducing divergence by questioning and renewing existing routines and competences. Again, this differs from the predominant outcomes of deliberate knowledge flows, which mainly seek convergence, integration, exploitation and limited deviance through the global replication of practices. Overall, our 
qualitative investigation of subsidiary managers' actual practices in knowledge mobilizations adds theoretical insights by developing a more stratified understanding of subsidiary knowledge inflows: depending on the different type of knowledge inflow (deliberate versus emergent) pursued, the typical activities and practices of subsidiary managers as well as front line employees and top management vary along different dimensions.

\subsection{Individual-level knowledge flows: Insights for micro-foundations of $M N C$} knowledge flows

While the investigation of organizational-level determinants of MNC and subsidiary knowledge flows has progressed considerably over the last years, efforts to understand and model individual-level agency and antecedents of knowledge flows have grown in significance more recently. There are, however, still significant research opportunities to further develop theory on the microfoundations of MNC knowledge flows (Doz, 2006; Foss, 2006; Foss \& Pedersen, 2004; Mäkelä et al., 2012; Michailova \& Mustaffa, 2012; Minbaeva et al., 2012).

Contributing to insights on the micro-foundations of knowledge flows, we were surprised by the limited extent to which subsidiary managers searched and mobilized external knowledge, given earlier observations of the positive impact of external embeddedness on competence development (Andersson, Forsgren, \& Holm, 2001, 2002) and suggestions that host-countries may offer unique, non-redundant, and context-specific knowledge (Meyer et al., 2011). However, a previous study on how managers source information also found that they search externally only occasionally (Cross \& Sproull, 2004) although managers may choose an external rather than internal source if unique 
knowledge is sought (King \& Lekse, 2006). Despite this surprising finding, the high proportion of cross-functional mobilizations suggests that subsidiary managers do not avoid seeking diverse knowledge, but choose more often to pursue it internally. It seems plausible that non-routine problem solving requires speedy access to additional knowledge, facilitated either via established external links or by exploiting the MNC's 'social community' advantages (Kogut \& Zander, 1992). Searching tacit external knowledge intensively may be more suited when a long-term cooperation for knowledge creation is envisaged, such as participating in external communities of practice or collaborating in alliances (Tallman \& Chacar, 2011a, 2011b). Also, most subsidiaries we studied had links to external partners located beyond their immediate host-country market or region: their external embeddedness has in fact become internationalized. Our findings demonstrate that; where very particular specialist expertise is needed, some subsidiary managers are willing to draw on these external, international links.

The findings of our study suggest that subsidiary managers are involved in two types of subsidiary knowledge inflows, and that these knowledge inflows exhibit contrasting features. Although the investigation of individual-level antecedents of deliberate and emergent knowledge flows is beyond the scope of this paper, there are strong reasons to expect that individual-level characteristics have a different effect on these knowledge inflows. Initiating emergent knowledge flows requires that the subsidiary managers exhibit a higher risktaking propensity and willingness to bear uncertainty as different knowledge components are explored for their suitability during the oftentimes complex search process. The same two traits, risk-taking propensity and willingness to 
bear uncertainty may impede deliberate knowledge flows, for example, if the subsidiary manager is more inclined to 'temper' with the competence in its current form by undertaking pre-mature adaptations to 'proven' inflowing processes and practices, which has been shown to reduce knowledge transfer effectiveness(Szulanski \& Jensen, 2006). It may also be plausible that emergent knowledge flows require more social capital that spans geographic distance and corporate functions in order to increase the subsidiary managers' ability to search for and source the more idiosyncratic and specialized knowledge required to develop innovative solutions to non-routine problems. In contrast, deliberate knowledge flow may benefit from within-subsidiary social capital in order to encourage the implementation of the received knowledge among local colleagues and front line employees.

\subsection{Limitations and future research}

As these discussions suggest, this paper has constructive implications for research on MNC knowledge flows at a micro-level. Although our findings are based on 40 cases sampled from four subsidiaries, which exhibit a range of organizational variables, the explorative nature of our inquiry calls for more investigations if the findings are to be generalized.

Future research on the micro-foundations of subsidiary managers' knowledge flows could also take into consideration the different features of deliberate and emergent knowledge flows, instead of treating knowledge inflows as a conflation of these two types of flows, to investigate their respective microfoundations. It seems particularly worthwhile to analyze the micro-foundations of diversity-introducing knowledge flows, for example by examining subsidiary 
managers' motivation for sourcing knowledge across functions and geographic distance as well as external to the MNC or subsidiary. As it is much easier for subsidiary managers to try to reuse 'proven' solutions or exchange locally and/or within their functional domains, further research is needed to explain when subsidiary managers perceive the need (and act) to generate divergent knowledge mobilizations. Given that we observed considerable variation in the numbers of knowledge components sourced, further research may also be able to disentangle the exact individual and organizational level reasons for this variance. Subsidiary managers rarely mobilized complete knowledge packages (such as full routines, processes or practices) but sourced elements selectively where they saw them as relevant (Schulz, 2003). Future studies could thus also explore how managers (or individuals more generally) assess which elements of the MNC's knowledge architecture can be meaningfully disaggregated and recombined. We did not specifically analyze whether the knowledge components represented location or non-location bound knowledge (Rugman \& Verbeke, 2001), or the translation work required to utilize knowledge from other locations, nor did we analyze in detail what knowledge was explored but not mobilized; further research could investigate these aspects. Given that applying a middle management perspective to questions of MNC knowledge flows yielded theoretical insights in this study, further studies could develop this research avenue: more fine-grained understanding of subsidiary managers' knowledge exchanges is needed to explore fully how their actions (or inactions) lead to creative and innovative (Kanter, 1982) and strategic outcomes (Floyd \& Wooldridge, 1994, 1999), and the influence of the MNC's knowledge governance mechanisms in directing their actions (Foss, 2007; Foss et al., 2010). 
We find that certain competence impacting knowledge flows may occur outside subsidiary and global top management visibility and direct control, and include mostly lateral and bottom up exchanges. This implies that these knowledge flows may not have been adequately captured by MNC knowledge flow studies built on data collected by surveying subsidiary top managers. We specifically suggest incorporating lower subsidiary and subunit management layers in such data collection efforts.

\subsection{Implications for managers}

Our study's findings also translate into several practice implications for MNC managers.Subsidiary managers' central position in MNC knowledge exchanges gives them a unique capacity to catalyze emergent knowledge flows. Our findings imply an increased need for subsidiary managers in operational units to become aware that their role in subsidiary knowledge inflows is broader thanoverseeing knowledge implementation.This involves being aware that nonroutine problems can be critical opportunities to move beyond deliberate knowledge flows to initiating emergent knowledge flows, i.e. knowledge exchanges that are much more explorative and capable of introducingknowledge diversity. This awareness also needs to incorporateopenness to exploring knowledge components from different functional unitsand across geographic space which might have significant potential to yieldnew recombination.

For MNC and subsidiary top management the findings imply that certain competence impacting knowledge flows occur outside their direct influenceandeven beyond their notice,and that the MNC's middle management layers are the locus of many (re-)combinative activities. While allocating 
competence creating mandates to certain subsidiaries distributesMNCresources efficiently, it is important torealize that all subsidiary managers (regardless of their unit affiliations) regularly face puzzles and new challenges, and that the extent to which they engage in emergent knowledge flows in response to such challenges influences the evolution ofMNC competences. While subsidiaries chartered with the execution of business activities rather than new competence creation may not have the resources and capabilities to achieve significant leaps for the MNC's competence base, they can also contribute with 'playful' and unexpected knowledge flows, realizing the kinds of knowledge reuse and recombination that are difficult for the more removed headquarters and top management to conceive. The decentralization ofsolution development, and the high specialization and distribution of MNCknowledge,can make it difficult for aMNC to know what it knows.Subsidiary managers can contribute here: by continuously browsingorganizational knowledge in their own ways to respond to unexpected problems they can discover novel uses for existing knowledge, also allowing subsidiary units, which may not be endowed with large or diverse knowledge bases, to create unique knowledge bundles to suit specific problems.

While top and headquarters management may be removed from many emergent knowledge flows, strong management influence is needed to support these activities.With regards to managing internal embeddedness, it seems important to allow for a diverse range of such interpersonal ties to provide channels for novel and unexpected knowledge mobilizations, so as to encourage subsidiary managers tobrowse the MNC's diverse knowledge pools on their own initiative, and for context specific reasons. Our findings also suggest that lateral and front-line interfaces are particularly helpful,implying that downward and 
horizontal embeddedness facilitates improved access to the tacit knowledge required to develop solutions.

\subsection{Conclusion}

Investigating in detail the actual practices and patterns of subsidiary managers'knowledge mobilizations when they encounter non-routine problems and search solutions to these specific challenges, this article contributes to discussions onMNCknowledge flows by providing previously missing microlevel detail about strategic patterns of knowledge circulation within MNCs. We used our exploratory insights to develop the contrasting notions of deliberate and emergent knowledge flows, highlighting how the emergent, i.e. largelybottom up, horizontaland boundary spanning subsidiary knowledge inflows locally as well as internationally initiated by subsidiary management can provide vital competence development elements. This is particularly the case with the increasing structural complexity ofMNCs, which are characterized by increasingly fine-sliced operations and correspondingly widedistribution and specializationof knowledge, and so rely more and more on their subsidiary managers to conceive and initiate novel patterns of knowledge inflows to realize the MNC's knowledge combination advantages. 


\section{Acknowledgements}

We thank the College of Business at Dublin Institute of Technology for funding this study. We are also grateful for comments provided by the reviewers and discussants at the Strategic Management Society Annual Conference (2011), the Strategic Management Society Conference Extension at Florida International University (2011), the European International Business Academy (2011), and the International Federation of Scholarly Associations of Management Conference (2012). 


\section{References}

Almeida, P., \& Phene, A. (2004). Subsidiaries and knowledge creation: The influence of the MNC and host country on innovation. Strategic Management Journal, 25: 847-864.

Ambos, T. C., \& Ambos, B. (2009). The impact of distance on knowledge transfer effectiveness in multinational corporations. Journal of International Management, 15: 1-14.

Andersson, U., Forsgren, M., \& Holm, U. (2001). Subsidiary embeddedness and competence development in MNCs: Multi-level analysis. Organization Studies, 22: 1013-1034.

Andersson, U., Forsgren, M., \& Holm, U. (2002). The strategic impact of external networks: Subsidiary performance and competence development in the multinational corporation. Strategic Management Journal, 23: 979997.

Argote, L., \& Ingram, P. (2000). Knowledge transfer: A basis for competitive advantage in firms. Organizational Behavior and Human Decision Processes, 82: 150-169.

Argote, L., Ingram, P., Levine, J. M., \& Moreland, R. L. (2000). Knowledge transfer in organizations: Learning from the experience of others. Organizational Behavior \& Human Decision Processes, 82: 1-8.

Argote, L., McEvily, B., \& Reagans, R. (2003). Managing knowledge in organizations: An integrative framework and review of emerging themes. Management Science, 49: 571-582.

Baden-Fuller, C., \& Winter, S. (2007). Replicating knowledge practices: Principles or templates? London: Cass Business School, City University.

Bartlett, C. A., \& Ghoshal, S. (1998). Managing across borders: The transnational solution (2nd ed.). London: Random House Business Books.

Birkinshaw, J., Hood, N., \& Jonsson, S. (1998). Building firm-specific advantages in multinational corporations: The role of subsidiary initiative. Strategic Management Journal, 19: 221-241. 
Björkman, I., Barner-Rasmussen, W., \& Li, L. (2004). Managing knowledge transfer in mncs: The impact of headquarters control mechanisms. Journal of International Business Studies, 35: 443-455.

Bonache, J., \& Zárraga-Oberty, C. (2008). Determinants of the success of international assignees as knowledge transferors: A theoretical framework. International Journal of Human Resource Management, 19: $1-18$.

Buckley, P. J. (2009). Internalisation thinking: From the multinational enterprise to the global factory. International Business Review, 18: 224-235.

Burgelman, R. A. (1983). Corporate entrepreneurship and strategic management: Insights from a process study. Management Science, 29: 1349-1364.

Ciabuschi, F., Dellestrand, H., \& Kappen, P. (2011). Exploring the effects of vertical and lateral mechanisms in international knowledge transfer projects. Management International Review (MIR), 51: 129-155.

Cross, R., \& Sproull, L. (2004). More than an answer: Information relationships for actionable knowledge. Organization Science, 15: 446-462.

Crowne, K. (2009). Enhancing knowledge transfer during and after international assignments. Journal of Knowledge Management, 13: 134-147.

Cyert, R. M., \& March, J. G. (1963). Behavioral theory of the firm. Englewood Cliffs, New Jersey: Prentice Hall Inc.

De Aiwis, G., Majid, S., \& Sattar Chaudhry, A. (2006). Transformation in managers' information seeking behaviour: A review of the literature. Journal of Information Science, 32: 362-377.

Dickmann, M., \& Harris, H. (2005). Developing career capital for global careers: The role of international assignments. Journal of World Business, 40: 399-408.

Dosi, G., Faillo, M., \& Marengo, L. (2008). Organizational capabilities, patterns of knowledge accumulation and governance structures in business firms: An introduction. Organization Studies, 29: 1165-1185.

Doz, Y. (2006). Knowledge creation, knowledge sharing and organizational structures and processes in MNCs: A commentary on Foss N. "Knowledge and organization in the theory of the MNC". Journal of Management \& Governance, 10: 29-33. 
Driffield, N., Love, J. H., \& Menghinello, S. (2010). The multinational enterprise as a source of international knowledge flows: Direct evidence from Italy. Journal of International Business Studies, 41: 350-359.

Eisenhardt, K. M. (1989). Building theory from case study research. Academy of Management Review, 14: 532-550.

Engelhard, J., \& Nägele, J. (2003). Organizational learning in subsidiaries of multinational companies in Russia. Journal of World Business, 38: 262.

Felin, T., \& Foss, N. J. (2005). Strategic organization: A field in search of microfoundations. Strategic Organization, 3: 441-455.

Felin, T., \& Hesterly, W. S. (2007). The knowledge-based view, nested heterogeneity, and new value creation: Philosophical considerations on the locus of knowledge. Academy of Management Review, 32: 195-218.

Floyd, S. W., \& Lane, P. J. (2000). Strategizing throughout the organization: Managing role conflicts in strategic renewal. Academy of Management Review, 25: 154-177.

Floyd, S. W., \& Wooldridge, B. (1994). Dinosaurs or dynamos? Recognizing middle management's strategic role. Academy of Management Executive, 8: 47-57.

Floyd, S. W., \& Wooldridge, B. (1999). Knowledge creation and social networks in corporate entrepreneurship: The renewal of organizational capability. Entrepreneurship: Theory \& Practice, 23: 123-143.

Foss, N. (2006). Knowledge and organization in the theory of the multinational corporation: Some foundational issues. Journal of Management \& Governance, 10: 3-20.

Foss, N. J. (2007). The emerging knowledge governance approach: Challenges and characteristics. Organization, 14: 29-52.

Foss, N. J., Husted, K., \& Michailova, S. (2010). Governing knowledge sharing in organizations: Levels of analysis, governance mechanisms, and research directions. Journal of Management Studies, 47: 455-482.

Foss, N. J., \& Pedersen, T. (2002). Transferring knowledge in MNCs: The role of sources of subsidiary knowledge and organizational context. Journal of International Management, 8: 49-68. 
Foss, N. J., \& Pedersen, T. (2004). Organizing knowledge processes in the multinational corporation: An introduction. Journal of International Business Studies, 35: 340-349.

Galunic, C. D., \& Rodan, S. (1998). Resource recombinations in the firm: Knowledge structures and the potential for Schumpeterian. Strategic Management Journal, 19: 1193-1201.

Ghoshal, S., \& Bartlett, C. A. (1988). Creation, adoption, and diffusion of innovations by subsidiaries of multinational corporations. Journal of International Business Studies, 19: 365-388.

Ghoshal, S., \& Bartlett, C. A. (1990). The multinational corporation as an interorganizational network. Academy of Management Review, 15: 603625 .

Ghoshal, S., Korine, H., \& Szulanski, G. (1994). Interunit communication in multinational corporations. Management Science, 40: 96-110.

Gnyawali, D. R., Singal, M., \& Mu, S. C. (2009). Knowledge ties among subsidiaries in MNCs: A multi-level conceptual model. Journal of International Management, 15: 387-400.

Gupta, A. K., \& Govindarajan, V. (1991). Knowledge flows and the structure of control within multinational corporations. Academy of Management Review, 16: 768-792.

Gupta, A. K., \& Govindarajan, V. (2000). Knowledge flows within multinational corporations. Strategic Management Journal, 21: 473-496.

Hansen, M. T. (1999). The search-transfer problem: The role of weak ties in sharing knowledge across organization subunits. Administrative Science Quarterly, 44: 82-111.

Hansen, M. T., \& Løvås, B. (2004). How do multinationals leverage technological competencies? Moving from single to interdependent explanations. Strategic Management Journal, 25: 801-822.

Hargadon, A. B., \& Bechky, B. A. (2006). When collections of creatives become creative collectives: A field study of problem solving at work. Organization Science, 17: 484-500.

Hedlund, G. (1994). A model of knowledge management and the $n$-form corporation. Strategic Management Journal, 15: 73-90. 
Henderson, R. M., \& Clark, K. B. (1990). Architectural innovation: The reconfiguration of existing product technologies and the failure of established firms. Administrative Science Quarterly, 35: 9-30.

Hocking, J. B., Brown, M., \& Harzing, A.-W. (2004). A knowledge transfer perspective of strategic assignment purposes and their path-dependent outcomes. International Journal of Human Resource Management, 15: 565-586.

Hocking, J. B., Brown, M., \& Harzing, A.-W. (2007). Balancing global and local strategic contexts: Expatriate knowledge transfer, applications, and learning within a transnational organization. Human Resource Management, 46: 513-533.

Hong, J. F. L., Snell, R. S., \& Easterby-Smith, M. (2009). Knowledge flow and boundary crossing at the periphery of a MNC. International Business Review, 18: 539-554.

Huber, G. P., \& Power, D. J. (1985). Retrospective reports of strategic-level managers: Guidelines for increasing their accuracy. Strategic Management Journal, 6: 171-180.

Inkpen, A. C., \& Tsang, E. W. K. (2005). Social capital, networks, and knowledge transfer. Academy of Management Review, 30: 146-165.

Kanter, R. M. (1982). The middle manager as innovator. Harvard Business Review, 60: 95-105.

King, W. R., \& Lekse, W. J. (2006). Deriving managerial benefit from knowledge search: A paradigm shift? Information \& Management, 43: 874-883.

Kogut, B., \& Zander, U. (1992). Knowledge of the firm, combinative capabilities, and the replication of technology. Organization Science, 3: 383-397.

Kogut, B., \& Zander, U. (1993). Knowledge of the firm and the evolutionary theory of the multinational corporation. Journal of International Business Studies, 24: 625-645.

Kostova, T. (1999). Transnational transfer of strategic organizational practices: A contextual perspective. Academy of Management Review, 24: 308-324. 
Kostova, T., \& Roth, K. (2002). Adoption of an organizational practice by subsidiaries of multinational corporations: Institutional and relational effects. Academy of Management Journal, 45: 215-233.

Kostova, T., \& Roth, K. (2003). Social capital in multinational corporations and a micro-macro model of its formation. Academy of Management Review, 28: 297-317.

Kotabe, M., Dunlap-Hinkler, D., Parente, R., \& Mishra, H. A. (2007).

Determinants of cross-national knowledge transfer and its effect on firm innovation. Journal of International Business Studies, 38: 259-282.

Lazarova, M., \& Tarique, I. (2005). Knowledge transfer upon repatriation. Journal of World Business, 40: 361-373.

Lincoln, Y. S., \& Guba, E. G. (1985). Naturalistic inquiry. Beverly Hills, CA: Sage.

Mäkelä, K., Andersson, U., \& Seppälä, T. (2011). Interpersonal similarity and knowledge sharing within multinational organizations. International Business Review: doi:10.1016/j.ibusrev.2011.1005.1003.

Mäkelä, K., Andersson, U., \& Seppälä, T. (2012). Interpersonal similarity and knowledge sharing within multinational organizations. International Business Review, 21: 439-451.

Mäkelä, K., \& Brewster, C. (2009). Interunit interaction contexts, interpersonal social capital, and the differing levels of knowledge sharing. Human Resource Management, 48: 591-613.

Meyer, K. E., Mudambi, R., \& Narula, R. (2011). Multinational enterprises and local contexts: The opportunities and challenges of multiple embeddedness. Journal of Management Studies, 48: 235-252.

Michailova, S., \& Mustaffa, Z. (2012). Subsidiary knowledge flows in multinational corporations: Research accomplishments, gaps, and opportunities. Journal of World Business, 47: 383-396.

Miles, M. B., \& Huberman, M. A. (1994). Qualitative data analysis: An expanded sourcebook. London: Sage.

Miller, C. C., Cardinal, L. B., \& Glick, W. H. (1997). Retrospective reports in organizational research: A reexamination of recent evidence. Academy of Management Journal, 40: 189-204. 
Minbaeva, D., Foss, N., \& Snell, S. (2009). Bringing the knowledge perspective into hrm. Human Resource Management, 48: 477-483.

Minbaeva, D. B., Mäkelä, K., \& Rabbiosi, L. (2012). Linking HRM and knowledge transfer via individual-level mechanisms. Human Resource Management, 51: 387-405.

Mintzberg, H., \& Waters, J. A. (1985). Of strategies, deliberate and emergent. Strategic Management Journal, 6: 257-272.

Mom, T. J. M., Van Den Bosch, F. A. J., \& Volberda, H. W. (2007). Investigating managers' exploration and exploitation activities: The influence of top-down, bottom-up, and horizontal knowledge inflows. Journal of Management Studies, 44: 910-931.

Monteiro, F., Arvidsson, N., \& Birkinshaw, J. (2008). Knowledge flows within multinational corporations: Explaining subsidiary isolation and its performance implications. Organization Science, 19: 90-107.

Mors, M. L. (2010). Innovation in a global consulting firm: When the problem is too much diversity. Strategic Management Journal, 31: 841-872.

Mudambi, R. (2002). Knowledge management in multinational firms. Journal of International Management, 8: 1.

Mudambi, R., \& Swift, T. (2009). Professional guilds, tension and knowledge management. Research Policy, 38: 736-745.

Mudambi, R., \& Swift, T. (2011). Leveraging knowledge and competencies across space: The next frontier in international business. Journal of International Management, 17: 186-189.

Nelson, R. R., \& Winter, S. G. (1982). An evolutionary theory of economic change. London: The Belknap Press of Harvard University Press.

Nickerson, J. A., \& Zenger, T. R. (2004). A knowledge-based theory of the firm: The problem-solving perspective. Organization Science, 15: 617-632.

Nonaka, I. (1994). A dynamic theory of organizational knowledge creation. Organization Science, 5: 14-37.

Noorderhaven, N., \& Harzing, A.-W. (2009). Knowledge-sharing and social interaction within MNEs. Journal of International Business Studies, 40: 719-741.

O'Donnell, S. (2000). Managing foreign subsidiaries: Agents of headquarters, or an interdependent network? Strategic Management Journal, 21: 525-548. 
Pauwels, P., \& Matthyssens, P. (2004). The architecture of multiple case study research in international business. In R. Marschan-Piekkari \& C. Welch (Eds.), Handbook of qualitative research methods for international business (pp. 125-143). Cheltenham, UK: Edward Elgar Publishing.

Phene, A., \& Almeida, P. (2008). Innovation in multinational subsidiaries: The role of knowledge assimilation and subsidiary capabilities. Journal of International Business Studies, 39: 901-919.

Polanyi, M. (1966). The tacit dimension. Garden City, New York: Doubleday and Co.

Poppo, L. (2003). The visible hands of hierarchy within the m-form: An empirical test of corporate parenting of internal product exchanges. Journal of Management Studies, 40: 403-430.

Regner, P., \& Zander, U. (2011). Knowledge and strategy creation in multinational companies. Management International Review (MIR), 51: $821-850$.

Rugman, A. M., \& Verbeke, A. (2001). Subsidiary-specific advantages in multinational enterprises. Strategic Management Journal, 22: 237-251.

Saka-Helmhout, A. (2009). Agency-based view of learning within the multinational corporation. Management Learning, 40: 258-274.

Saka-Helmhout, A. (2010). Organizational learning as a situated routine-based activity in international settings. Journal of World Business, 45: 41-48.

Schulz, M. (2001). The uncertainty of relevance of newness: Organizational learning and knowledge flows. Academy of Management Journal, 44: 661-681.

Schulz, M. (2003). Pathways of relevance: Exploring inflows of knowledge into subunits of multinational corporations. Organization Science, 14: 440459.

Simon, H. A. (1962). The architecture of complexity. Proceedings of the American Philosophical Society, 106: 467-482.

Sunaoshi, Y., Kotabe, M., \& Murray, J. Y. (2005). How technology transfer really occurs on the factory floor: A case of a major Japanese automotive die manufacturer in the united states. Journal of World Business, 40: 5770. 
Szulanski, G. (1996). Exploring internal stickiness: Impediments to the transfer of best practice within the firm. Strategic Management Journal, 17: 2743.

Szulanski, G. (2000). Appropriability and the challenge of scope: Banc one routinizes replication. In G. Dozi, R. R. Nelson \& S. G. Winter (Eds.), The nature and dynamics of organizational capabilities (pp. 69-98). New York: Oxford University Press.

Szulanski, G., \& Jensen, R. J. (2006). Presumptive adaptation and the effectiveness of knowledge transfer. Strategic Management Journal, 27: 937-957.

Tallman, S., \& Chacar, A. S. (2011a). Communities, alliances, networks and knowledge in multinational firms: A micro-analytic framework. Journal of International Management, 17: 201-210.

Tallman, S., \& Chacar, A. S. (2011b). Knowledge accumulation and dissemination in MNEs: A practice-based framework. Journal of Management Studies, 48: 278-304.

Taylor, A., \& Helfat, C. E. (2009). Organizational linkages for surviving technological change: Complementary assets, middle management, and ambidexterity. Organization Science, 20: 718-739.

Teigland, R., \& Wasko, M. (2009). Knowledge transfer in MNCs: Examining how intrinsic motivations and knowledge sourcing impact individual centrality and performance. Journal of International Management, 15: 15-31.

Tippmann, E., Scott, P., \& Mangematin, V. (2010). Learning in distributed organizations: How subsidiary middle managers do (not) create global solutions., Strategic Management Society 30th International Conference. Rome, Italy.

Tsai, W. (2000). Social capital, strategic relatedness and the formation of intraorganizational linkages. Strategic Management Journal, 21: 925.

Tsai, W. (2001). Knowledge transfer in intraorganizational networks: Effects of network position and absorptive capacity on business unit innovation and performance. Academy of Management Journal, 44: 996-1004. 
Tsai, W. (2002). Social structure of "Coopetition" Within a multiunit organization: Coordination, competition, and intraorganizational knowledge sharing. Organization Science, 13: 179-190.

Tsai, W., \& Ghoshal, S. (1998). Social capital and value creation: The role of intrafirm networks. Academy of Management Journal, 41: 464-476.

van Wijk, R., Jansen, J. J. P., \& Lyles, M. A. (2008). Inter- and intraorganizational knowledge transfer: A meta-analytic review and assessment of its antecedents and consequences. Journal of Management Studies, 45: 830-853.

Winter, S. G. (2003). Understanding dynamic capabilities. Strategic Management Journal, 24: 991-995.

Yamin, M., Tsai, H.-J. S., \& Holm, U. (2011). The performance effects of headquarters' involvement in lateral innovation transfers in multinational corporations. Management International Review (MIR), 51: 157-177.

Yin, R. K. (2009). Case study research: Design and methods (4th ed.). Thousand Oaks, CA: Sage Publications, Inc.

Zander, U., \& Kogut, B. (1995). Knowledge and the speed of the transfer and imitation of organizational capabilities: An empirical test. Organization Science, 6: 76-92.

Zellmer-Bruhn, M. E. (2003). Interruptive events and team knowledge acquisition. Management Science, 49: 514-528.

Zollo, M., \& Winter, S. G. (2002). Deliberate learning and the evolution of dynamic capabilities. Organization Science, 13: 339-351. 
Table 1

Characteristics of sample organizations

\begin{tabular}{|c|c|c|c|c|c|c|}
\hline Organization & $\begin{array}{l}\text { Principal sub- } \\
\text { domain in ICT } \\
\text { industry }\end{array}$ & $\begin{array}{l}\text { Approximate size } \\
\text { of MNC } \\
\text { (total no. employees } \\
\text { at end2010) }\end{array}$ & $\begin{array}{l}\text { Positioning of focal subsidiary } \\
\text { in international operations } \\
\text { (structure of international } \\
\text { operations, scope of } \\
\text { mandate,autonomy) }\end{array}$ & $\begin{array}{l}\text { Approximate size } \\
\text { of focal } \\
\text { subsidiary } \\
\text { (total no. employees } \\
\text { at end } 2010 \text { ) }\end{array}$ & $\begin{array}{l}\text { Units located at focal } \\
\text { subsidiary } \\
\text { (end of 2010) }\end{array}$ & $\begin{array}{l}\text { Units used for } \\
\text { data collection } \\
\text { (to select middle } \\
\text { managers) }\end{array}$ \\
\hline Epsilon & $\begin{array}{l}\text { ICT solutions and } \\
\text { related services }\end{array}$ & $50,000-100,000$ & $\begin{array}{l}\text { - Other subsidiaries reporting to } \\
\text { focal subsidiary } \\
\text { - } \quad \text { Global responsibilities } \\
\text { - } \quad \text { High autonomy }\end{array}$ & $>1,500$ & $\begin{array}{l}\text { - } \quad \text { R\&D } \\
\text { - } \quad \text { Services } \\
\text { (two separate units) }\end{array}$ & - $\quad \mathrm{R} \& \mathrm{D}$ \\
\hline Gamma & ICT services & $<50,000$ & $\begin{array}{l}\text { - One of three sister } \\
\text { subsidiaries, regional } \\
\text { headquarter } \\
\text { - } \quad \text { Local and regional } \\
\text { responsibilities } \\
\text { - } \quad \text { High autonomy }\end{array}$ & $<1,500$ & $\begin{array}{l}\text { - Sales } \\
\text { (two separate units) }\end{array}$ & - Sales \\
\hline Omega & $\begin{array}{l}\text { Hardware, } \\
\text { software, } \\
\text { solutions and } \\
\text { related services }\end{array}$ & $>100,000$ & $\begin{array}{l}\text { - Similar sister units in other } \\
\text { locations, structural } \\
\text { interdependencies } \\
\text { - } \quad \text { Regional and global } \\
\text { responsibilities } \\
\text { - } \\
\text { Moderate autonomy }\end{array}$ & $>1,500$ & $\begin{array}{l}\text { - } \text { Operations } \\
\text { - } \quad \text { Sales } \\
\text { - } \quad \text { Services } \\
\text { - } \quad \text { R\&D } \\
\text { (four separate units) }\end{array}$ & $\begin{array}{l}\text { - Operations } \\
\text { - } R \& D\end{array}$ \\
\hline Sigma & $\begin{array}{l}\text { Software } \\
\text { solutions and } \\
\text { related services }\end{array}$ & $50,000-100,000$ & $\begin{array}{l}\text { - Part of tightly integrated and } \\
\text { interdependent network } \\
\text { - Local, regional and global } \\
\text { responsibilities } \\
\text { - Low autonomy }\end{array}$ & $<1,500$ & $\begin{array}{l}\text { - } \text { Sales } \\
\text { - } \quad \text { Services \& Support } \\
\text { - } \quad \text { R\&D } \\
\text { (over } 15 \text { separate units) }\end{array}$ & $\begin{array}{ll}\text { - } & \text { Sales } \\
\text { - } & \text { Services \& } \\
& \text { Support }\end{array}$ \\
\hline
\end{tabular}


Table 2

Characteristics of sample non-routine problems

\begin{tabular}{|c|c|c|}
\hline $\begin{array}{l}\text { Subsidiary, } \\
\text { case }\end{array}$ & Non-routine problem & $\begin{array}{c}\text { No. of knowledge } \\
\text { components } \\
\text { mobilized }\end{array}$ \\
\hline \multicolumn{3}{|l|}{ Epsilon } \\
\hline Case 1 & Difficulties transferring an unusually complex technology & 1 \\
\hline Case 2 & Challenge in improving internal process & 6 \\
\hline Case 3 & Issues with outsourcing operations & 3 \\
\hline Case 4 & Issues with internal process & 0 \\
\hline Case 5 & Issues with outsourcing operations & 3 \\
\hline Case 6 & Difficulties with practices of managing virtual teams & 2 \\
\hline Case 7 & Issues with practices for governing outsourced operations & 1 \\
\hline Case 8 & Difficulties transferring an unusually complex technology & 2 \\
\hline \multicolumn{3}{|c|}{ 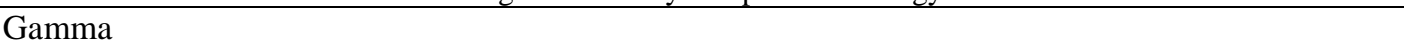 } \\
\hline Case 1 & Incidence in people management & 4 \\
\hline Case 2 & Issue with sales practices & 2 \\
\hline Case 3 & Incidence in people management & 3 \\
\hline Case 4 & Challenges in developing sales business in emerging market & 2 \\
\hline Case 5 & Challenges in developing integration with another sales unit & 2 \\
\hline Case 6 & Challenge in designing processes for a newly set up team & 3 \\
\hline Case 7 & $\begin{array}{l}\text { Challenge in developing processes and practices for new } \\
\text { organizational structure }\end{array}$ & 3 \\
\hline Case 8 & Issue in optimizing and automating current sales processes & 2 \\
\hline Case 9 & $\begin{array}{l}\text { Challenge in designing processes and structures for new } \\
\text { organizational structure }\end{array}$ & 5 \\
\hline Case 10 & $\begin{array}{l}\text { Challenges in dealing with increase in business demand and } \\
\text { associated design of outsourcing operations }\end{array}$ & 8 \\
\hline Case 11 & $\begin{array}{l}\text { Challenge in developing processes and practices for new } \\
\text { organizational structure }\end{array}$ & 7 \\
\hline Case 12 & Issue with customer loyalty & 8 \\
\hline Case 13 & Challenge in optimizing and automating operations & 10 \\
\hline \multicolumn{3}{|c|}{ 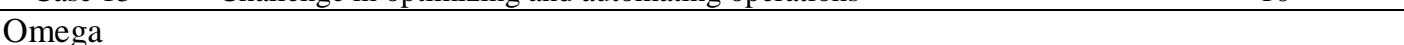 } \\
\hline Case 1 & Issue in managing large-scale $\mathrm{R} \& \mathrm{D}$ program & 5 \\
\hline Case 2 & Difficulties with operations of production line & 4 \\
\hline Case 3 & Challenges in setting up processes for a new team & 1 \\
\hline Case 4 & Challenge in reshaping practices of a unit & 0 \\
\hline Case 5 & Difficulties with efficiency of process & 2 \\
\hline Case 6 & $\begin{array}{l}\text { Challenge in developing processes and technology for product } \\
\text { change }\end{array}$ & 4 \\
\hline Case 7 & Resolve serious technical escalation & 9 \\
\hline Case 8 & Challenges in optimizing the operations for higher volume capacity & 6 \\
\hline Case 9 & Resolve particularly difficult technical escalation & 7 \\
\hline \multicolumn{3}{|c|}{ 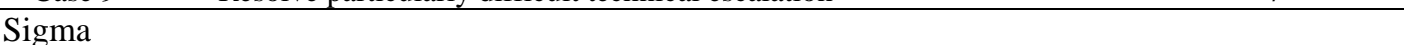 } \\
\hline Case 1 & Challenge in people management & 1 \\
\hline Case 2 & Issues in designing structures and processes for a new unit & 6 \\
\hline Case 3 & Difficulties with processes and practices of acquired unit & 3 \\
\hline Case 4 & $\begin{array}{l}\text { Challenges in optimizing the current operations to deal with sudden } \\
\text { increase in demand }\end{array}$ & 4 \\
\hline Case 5 & Challenge in improving efficiency of operations & 1 \\
\hline Case 6 & $\begin{array}{l}\text { Difficulties in designing new processes for changes organizational } \\
\text { structure }\end{array}$ & 2 \\
\hline Case 7 & $\begin{array}{l}\text { Issue in improving quality of operations and finding an automated } \\
\text { solution }\end{array}$ & 4 \\
\hline Case 8 & Difficulties in rolling out processes and practices & 4 \\
\hline Case 9 & Challenge in tracing product quality issue & 3 \\
\hline Case 10 & $\begin{array}{l}\text { Issue in resolving product quality issue with seriously negative } \\
\text { business impact }\end{array}$ & 3 \\
\hline 40 cases & & $\begin{array}{l}146 \text { knowledge } \\
\text { components }\end{array}$ \\
\hline
\end{tabular}




\section{Table 3}

Representative supporting data for each knowledge component theme

\begin{tabular}{|c|c|c|}
\hline & $\begin{array}{l}\text { Knowledge flow } \\
\text { theme }\end{array}$ & Representative supporting data \\
\hline \multirow[t]{2}{*}{ Explicit } & $\begin{array}{l}\text { Declarative } \\
\text { knowledge }\end{array}$ & $\begin{array}{l}\text { "A lot of background knowledge and numbers. A lot } \\
\text { of additional details: the number of incoming } \\
\text { messages in each location, the number of } \\
\text { messages affected. Targets." (Sigma, case 4) }\end{array}$ \\
\hline & $\begin{array}{l}\text { Practice - process } \\
\text { embedded in } \\
\text { document, } \\
\text { tools, } \\
\text { technology }\end{array}$ & $\begin{array}{l}\text { "It would be documented in different documents or in } \\
\text { power point slides. It can be pulled together ... } \\
\text { there would be documents here, here, here, and } \\
\text { here of each of the individual subcomponents } \\
\text { within the overall process." (Epsilon, case 2) }\end{array}$ \\
\hline \multirow[t]{3}{*}{ Tacit } & $\begin{array}{l}\text { Practice - } \\
\text { understanding } \\
\text { of practice }\end{array}$ & $\begin{array}{l}\text { "Really just questioning them on what information } \\
\text { they could provide on how they worked, how they } \\
\text { renewed to their customers, and how they sold to } \\
\text { their customers." (Sigma, case 3) }\end{array}$ \\
\hline & $\begin{array}{l}\text { Experience, } \\
\text { advice }\end{array}$ & $\begin{array}{l}\text { "So you just go to the team and say: 'Listen, we are } \\
\text { observing this, why do you think this is } \\
\text { happening?' This is the informal, very practical } \\
\text { experience." (Gamma, case 12) }\end{array}$ \\
\hline & $\begin{array}{l}\text { Specialist } \\
\text { expertise, } \\
\text { competence }\end{array}$ & $\begin{array}{l}\text { "We were trying to have knowledge, for example, } \\
\text { from one specialist team. It is the Sales } \\
\text { Management team." (Gamma, case 12) }\end{array}$ \\
\hline
\end{tabular}




\section{Table 4}

Summary of frequency of knowledge flow data

\begin{tabular}{llcc}
\hline Knowledge component theme & $\begin{array}{c}\text { No. of cases mentioned } \\
\text { (of 40) }\end{array}$ & $\begin{array}{c}\text { No. of knowledge } \\
\text { components (of 146) }\end{array}$ \\
\hline Explicit & Declarative knowledge & 16 & 18 \\
& Practice - process embedded in & 15 & 23 \\
& document, tools, technology & & \\
\hline Tacit & Practice - understanding of practice & 14 & 18 \\
& Experience, advice & 22 & 34 \\
& Specialist expertise, competence & 22 & 53 \\
\hline \multirow{2}{*}{ Analysis of knowledge diversity } & No. of cases mentioned & No. of exchanges (of \\
& Internal: within-function & 35 & $\mathbf{1 2 2})$ \\
\hline Internal: cross-function & 28 & 54 \\
& External & 10 & 51 \\
\hline
\end{tabular}


Table 5

Comparison of perspectives on MNC knowledge flows

\section{Deliberate knowledge flow Emergent knowledge flow}

Top-down

Bottom up

\begin{tabular}{|c|c|c|}
\hline \multirow{2}{*}{$\begin{array}{l}\text { MNC (Top) } \\
\text { management }\end{array}$} & \multicolumn{2}{|c|}{ Helicopter perspective on MNC capability composition and capability distribution } \\
\hline & $\begin{array}{l}\text { Direct knowledge inflow / } \\
\text { replication } \\
\text { - Initiation of or influence over of } \\
\text { knowledge inflow to subsidiary }\end{array}$ & $\begin{array}{l}\text { - Legitimize and support diverse } \\
\text { knowledge flows and competence } \\
\text { development } \\
\text { - Facilitate adaptability and renewal }\end{array}$ \\
\hline $\begin{array}{l}\text { Subsidiary } \\
\text { (Middle) } \\
\text { management }\end{array}$ & $\begin{array}{l}\text { Implementer: oversee } \\
\text { implementation of knowledge, } \\
\text { enforce adoption }\end{array}$ & $\begin{array}{l}\text { - Initiationof knowledge inflow } \\
\text { - Search for existing practice } \\
\text { (functional and cross-functional) } \\
\text { plus other, often tacit knowledge } \\
\text { components } \\
\text { - Opportunity for boundary } \\
\text { spanning / cross-functional } \\
\text { knowledge mobilization. Important } \\
\text { locus of (re-) combinative } \\
\text { activities. }\end{array}$ \\
\hline Front-line & $\begin{array}{ll}\text { - } & \text { Implementation and internalization } \\
\text { (Kostova, 1999) } \\
\text { - Adaptations - knowing in practice } \\
\text { (Hong, Snell, \& Easterby-Smith, } \\
\text { 2009; Saka-Helmhout, 2009, 2010) } \\
\text { - Risk of minimal and ceremonial } \\
\text { adoption (Kostova and Roth, 2002) }\end{array}$ & $\begin{array}{l}\text { - Assist solution seeking by } \\
\text { providing understanding of } \\
\text { practice, specialist skill / } \\
\text { competence, experience / advice }\end{array}$ \\
\hline $\begin{array}{l}\text { Dominant } \\
\text { forces }\end{array}$ & $\begin{array}{l}\text { Within business unit (within } \\
\text { function, leverage best practices) } \\
\text { Convergence / uniformity (global } \\
\text { integration in that units should } \\
\text { operate similar practices) }\end{array}$ & $\begin{array}{l}\text { Within and across business unit } \\
\text { (within and cross functional). } \\
\text { Divergence (competence } \\
\text { development, questions existing } \\
\text { routines) } \\
\text { - Potential for innovative and } \\
\text { creative solutions }\end{array}$ \\
\hline
\end{tabular}




\section{Figure 1}

Summary of mobilizedinternalknowledge components from a subsidiary management perspective ${ }^{\mathrm{a}}$

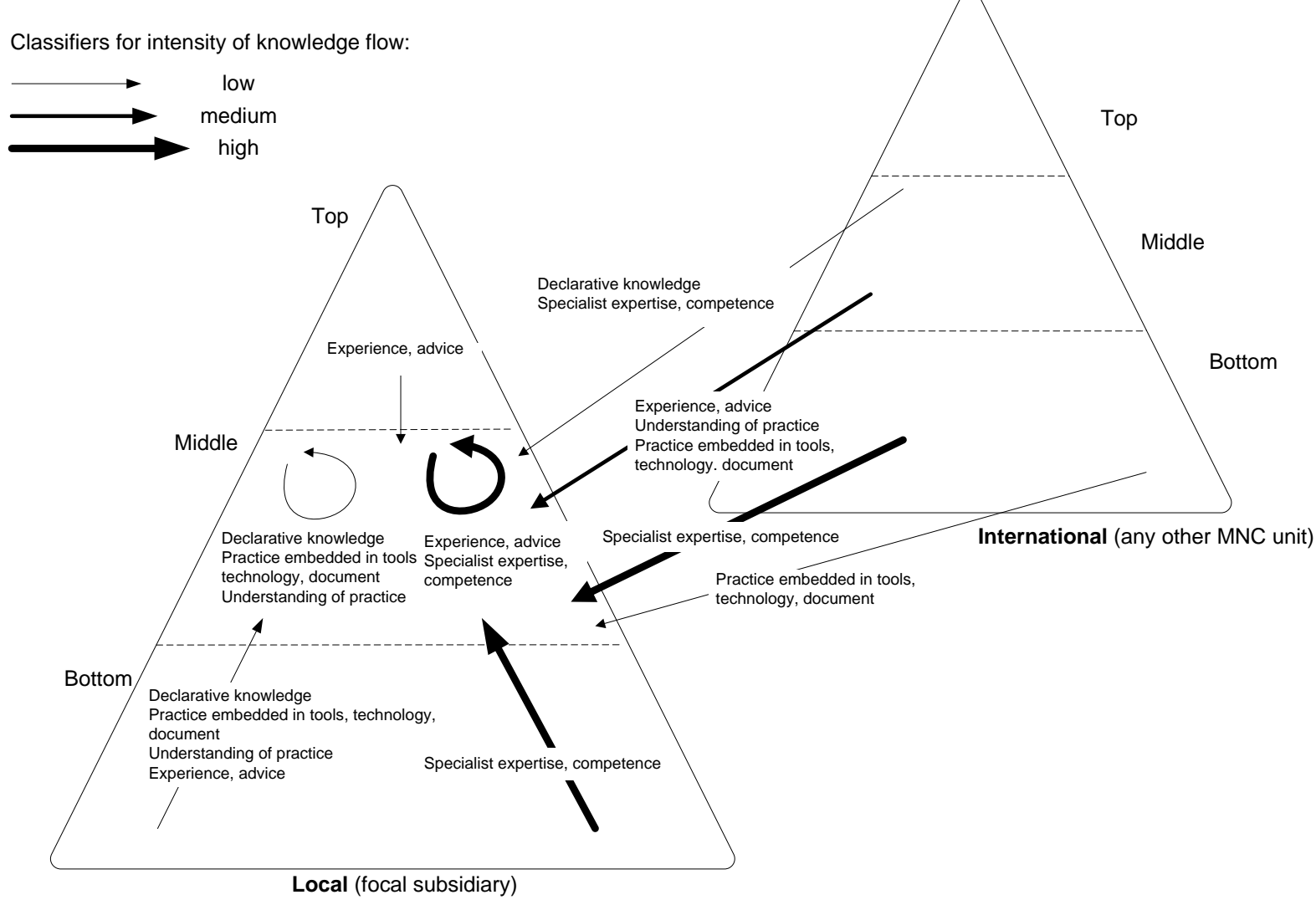

${ }^{a}$ The frequencies were classified as low if the data set included 3-5 occurrences, medium if the dataset included $6-10$ occurrences, high if the dataset included $11-15$ occurrences. As this analysis was concerned with overall patterns, arrowsrepresenting less than 3 occurrences are not presented. 